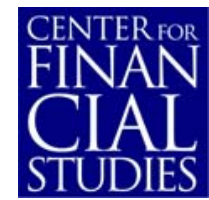

No. $2007 / 19$

Competition between Exchanges:

Euronext versus Xetra

Maria Kasch-Haroutounian and Erik Theissen 


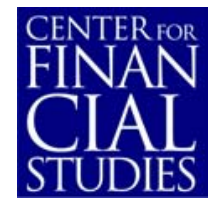

\section{Center for Financial Studies}

The Center for Financial Studies is a nonprofit research organization, supported by an association of more than 120 banks, insurance companies, industrial corporations and public institutions. Established in 1968 and closely affiliated with the University of Frankfurt, it provides a strong link between the financial community and academia.

The CFS Working Paper Series presents the result of scientific research on selected topics in the field of money, banking and finance. The authors were either participants in the Center's Research Fellow Program or members of one of the Center's Research Projects.

If you would like to know more about the Center for Financial Studies, please let us know of your interest.

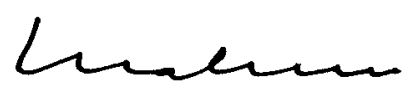

Prof. Dr. Jan Pieter Krahnen

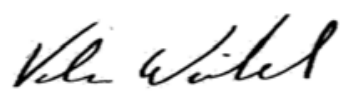

Prof. Volker Wieland, Ph.D. 
CFS Working Paper No. 2007/19

\title{
Competition between Exchanges: Euronext versus Xetra*
}

\section{Maria Kasch-Haroutounian ${ }^{1}$ and Erik Theissen ${ }^{2}$}

\section{November 2006}

\begin{abstract}
:
Exchanges in Europe are in a process of consolidation. After the failure of the proposed merger between Deutsche Börse and Euronext, these two groups are likely to become the nuclei for further mergers and co-operation with currently independent exchanges. A decision for one of the groups entails a decision for the respective trading platform. Against that background we evaluate the attractiveness of the two dominant continental European trading systems. Though both are anonymous electronic limit order books, there are important differences in the trading protocols. We use a matched-sample approach to compare execution costs in Euronext Paris and Xetra. We find that both quoted and effective spreads are lower in Xetra. When decomposing the spread we find no systematic differences in the adverse selection component. Realized spreads, on the other hand, are significantly higher in Euronext. Neither differences in the number of liquidity provision agreements nor differences in the minimum tick size or in the degree of domestic competition for order flow explain the different spread levels. We thus conclude that Xetra is the more efficient trading system.
\end{abstract}

JEL Classification: G10, G15

Keywords: Competition between Exchanges, Bid-ask Spread

\footnotetext{
* We thank John Doukas, Rudy De Winne, an anonymous referee, participants of the 2005 SUERF seminar on the Consolidation of European Securities Markets, of the 2003 annual meeting of the European Financial Management Association, of the Second Workshop of the ECB-CFS Research Network on Capital Markets and Financial Integration in Europe, and of the 9th Symposium on Finance Banking and Insurance in Karlsruhe for help-ful comments. Financial support from Deutsche Forschungsgemeinschaft through SFB/TR15 is gratefully acknowledged.

1 University of Bonn, E-mail: mkasch@uni-bonn.de

2 University of Bonn and CFS, E-mail: theissen@uni-bonn.de
} 


\section{Introduction}

European exchanges are in a process of consolidation. Banks and institutional investors are putting pressure on exchange officials to decrease transaction costs. The fragmentation of European exchanges has been identified as one source of high transaction costs. Mergers between exchanges and the joint use of trading systems are considered to be part of the solution. ${ }^{1}$ As Jacques de Larosiere, former governor of the Banque de France and former president of the European Bank for Reconstruction and Development, puts it: ${ }^{2}$

At national and cross-border level [...] traditional stock markets are being obliged to regroup in order to secure the economies of scale essential if they are to become competitive at European level.

Currently there are two major players in continental Europe, Euronext and Deutsche Börse. In 2000 the French Stock Exchange (ParisBourseSBF SA.) merged with the exchanges in Amsterdam, Brussels and (in 2002) Lisboa to form Euronext. The common trading platform has been in operation since 2001. The London-based derivatives exchange LIFFE joined the Euronext group in 2002. Deutsche Börse AG merged its derivatives trading subsidiary, Deutsche Terminbörse AG, with the Swiss derivatives exchange SOFFEX to form EUREX which became the world's largest derivatives exchange. The exchanges in Austria and Ireland have adopted Deutsche Börse's electronic trading system Xetra.

Deutsche Börse has recently proposed a merger with Euronext. Under the terms of the proposal, Deutsche Börse would have abandoned its trading system Xetra in favor of Euronext's trading system. Despite political pressure in favour of a "European solution" Euronext re-

1 For a theoretical treatment of the issue see di Noia (2001).

2 The statement was made in a speech at the Brussels Economic Forum in May 2002. The manuscript can be downloaded at http://www.asmp.fr/fiches_academiciens/textacad/larosiere/eurofi.pdf. 
jected the offer and rather decided to merge with the New York Stock Exchange. In November 2006 Deutsche Börse AG officially withdrew its offer.

As a consequence, the two trading systems, Xetra and Euronext, will continue to coexist. Deutsche Börse has already announced that it will seek to grow in Middle and Eastern Europe and in Asia. The NYSE-Euronext group is likely to pursue similar goals. Thus, the process of consolidation among European exchanges will continue and will lead currently independent exchanges to join the NYSE-Euronext group or Deutsche Börse, either by way of a merger or by way of cooperation. The decision to join either group entails a choice between the two trading systems. The quality of the trading system, although certainly not the only criterion, should play a role in that decision. Recently published plans by a group of large investment banks to establish a pan-European trading platform for stocks will increase the pressure on exchanges to strive for efficiency.

Against that background a comparison of the trading systems of Euronext and Deutsche Börse is certainly warranted. The objective of our paper is to provide such a comparison. We create matched samples of stocks that are similar with respect to the characteristics that are known to determine the bid-ask spread. Using market capitalization, trading volume, price and volatility as matching criteria we form two samples of 40 pairs of stocks each. A pair consists of one French stock traded on Euronext Paris and one German stock traded in Xetra. Our approach is similar to that of Venkataraman (2001), Ellul (2002) and Gajewski and Gresse (2004). The analysis relies on intradaily data and on transaction cost measures that are standard in the microstructure literature.

The main results can be summarized as follows. Both quoted and effective spreads are lower in Xetra. We decompose the spread into an adverse selection component and the realized spread and find that there are no systematic differences in the adverse selection component 
whereas the realized spreads are lower in Xetra. This results indicates that Euronext offers lower operational efficiency.

We then test whether differences in market organization can explain these findings. Specifically, we consider differences in the number of liquidity provision agreements, and differences in the minimum tick size. None of these characteristics fully explains the higher execution costs in Euronext. Finally, we test whether (domestic) competition for order flow has a bearing on the transaction costs. Euronext Paris does not face domestic competition. In Germany, on the other hand, Xetra competes with the floor of the Frankfurt stock exchange and several regional exchanges. The intensity of the competitive pressure, as measured by the market share of Xetra, varies considerably across stocks. When including this variable in our analysis, however, we find that the degree of domestic competition does not explain the differences in execution costs either.

These results are of importance to exchanges, corporations, investors, and regulators. They suggest that Xetra is the more efficient trading system. This result should be taken into consideration when currently independent exchanges decide whether to join one of the two large groups. A failure to opt for the more efficient trading system may result in an elevated level of execution costs for investors, higher cost of equity for corporations and generally a lower level of operational efficiency.

The paper is organized as follows. Section 2 contains a brief survey of the literature. In section 3 we provide a detailed description of the trading systems under scrutiny. Section 4 describes the data set and the matching procedure and presents descriptive statistics. In section 5 we compare the transaction costs in Xetra and Euronext. Section 6 is devoted to attempts at explaining the differences in transaction costs. Section 7 offers a concluding discussion. 


\section{A Brief Survey of the Literature}

When comparing execution costs across exchanges it is necessary to take into account the fact that there are differences in the characteristics of the listed companies. In order to trace differences in execution costs back to the design of the trading systems one thus needs to control for stock characteristics.

There are two principal approaches to achieve this. The first is to analyze identical stocks traded in both markets, e.g. French stocks which are cross-listed in Xetra or vice versa. This approach has (among others) been used by Pagano and Röell (1990), Schmidt and Iversen (1993), de Jong, Nijman and Röell (1995) and Degryse (1997) to compare the cost of trading continental European stocks in their home market and in the London-based SEAQ system. The disadvantage of analyzing cross-listed stocks is that the home market has a natural liquidity advantage (Piwowar 1997). Adopting this approach would most likely yield the result that Euronext Paris offers lower trading costs for French stocks whereas Xetra offers lower costs for German stocks.

The second approach is to compare stocks which are similar with respect to those characteristics that determine liquidity. The resulting matched sample procedure has been used to compare execution costs on NYSE and Nasdaq (Affleck-Graves, Hedge and Miller, 1994; Huang and Stoll, 1996; Bessembinder and Kauffman, 1996) and in pure limit order books, hybrid systems and dealership markets (Ellul 2002). Venkataraman (2001) uses a matched sample approach to compare US stocks listed on the NYSE and French stocks traded in NSC (the predecessor of Euronext Paris). His focus is on comparing floor-based and electronic trading. Gajewski and Gresse (2004) compare transaction costs on Euronext Paris to those on the London Stock Exchange. Ellul (2002) compares French stocks traded on the CAC system (the predecessor of NSC), German stocks traded on IBIS (the predecessor of 
Xetra) and UK stocks traded on the SEAQ system. These systems differ with respect to the degree of dealer intervention. He finds that spreads in IBIS are the lowest.

Some recent papers have performed multi-country comparisons of execution costs. Domowitz, Glen and Madhavan (2001) report one-way implicit costs (basically a variant of the effective half-spread) of $0.067 \%$ for France and $0.134 \%$ for Germany. The data covers the years 1995-98. The paper does not provide information on the composition of the sample. It is unclear whether the data for Germany is from the floor of the Frankfurt Stock Exchange or from the electronic trading system (IBIS until November 1997, Xetra thereafter), and no information on the number and characteristics of the firms included in the sample is provided.

Based on unmatched samples of 250 stocks each, Swan and Westerholm (2004) report that average effective spreads are $1.00 \%$ in Xetra but only 0.46\% in Euronext. Jain (2001) finds an average quoted spread of 3.65\% for the sample of all German stocks ( $0.86 \%$ for the 15 largest firms) and of 3.60\% for the sample of all French stocks (0.23\% for the 15 largest firms). London Economics (2002) reports effective spreads of 5.27\% for Germany and $6.83 \%$ for France. $^{3}$ The results of these multi-country comparisons differ by several orders of magnitude. This may, at least in part, be due to two inherent drawbacks of the approach. First, in a multi-country analysis it is difficult, if not impossible, to control for differing stock characteristics. Second, data requirements are very high as data for all countries in the sample is needed. The country with the lowest level of data availability determines the design of the

3 This study, a report to the European Commission, raises questions about the methodology used. The authors claim (p. 24) that they are using daily closing bid, ask, and transaction prices. However, the number of German stocks included in their study far exceeds the number of continuously traded domestic stocks. The same is true for French stocks, as pointed out by Davydoff et al. (2002). This raises the question of how bid and ask prices for stocks that only trade in a call auction are defined, and how they are used to calculate spread measures. 
study. As a consequence, multi-country studies are often based on less detailed data sets than bilateral comparisons. $^{4}$

\section{Equity Trading on Euronext Paris and Xetra}

The two trading systems share many similarities. Most importantly, they are both anonymous electronic open limit order books. However, closer inspection reveals that there are a number of potentially important differences. In this section we give a short description of both trading systems. It is complemented by the more detailed information given in Table 1 .

\section{Insert Table 1 about here}

Euronext is the result of a merger between the exchanges in France, the Netherlands, and Belgium. The trading system goes back to the Cotation Assisté en Continue (CAC) system introduced in 1986, later renamed Nouvelle Systeme de Cotation (NSC). After the merger in 2001, several changes were implemented to harmonize the trading protocols on the three markets. Liquid stocks are traded continuously from 09.00 to 17.25 , with call auctions at the open and close of trading. The market is fully transparent, with the exception of the hidden part of "iceberg orders". Only a fraction of the volume of these orders (the "peak") is visible on the screen. After execution of the peak, the next, equally-sized, part of the order becomes visible. ${ }^{5}$ Crosses and block trades may be negotiated outside the system. The admissible prices for these transactions are restricted by the status of the order book. Reporting requirements assure that they are funnelled through the system.

4 Domowitz et al. (2000) use data provided by Elkins, McSherry Co., Inc., an advisory firm. Costs are measured by relating the prices realized in institutional equity trades to a benchmark which is constructed as the average of the daily high, low, opening and closing prices. Both Jain (2001) and London Economics (2002) base their analysis on daily closing bid and ask prices obtained from Bloomberg.

5 When the total order is not a multiple of the peak volume, the last part is smaller than the preceding parts. A further characteristic of the iceberg orders is that each portion is attached the time stamp of the moment when it becomes visible. The hidden parts therefore lose time priority. 
For some less liquid stocks, liquidity providers stand ready to increase the liquidity. They have to commit to posting firm two-way quotes. The definition of maximum spreads and minimum depths is part of the agreement with Euronext. Volatility interruptions are triggered when the potential transaction price would lie outside a pre-defined range around a reference price.

The trading system Xetra was introduced in November 1997 and replaced the electronic trading system IBIS. Liquid stocks are traded continuously from 09.00 to 20.00 with call auctions at the open, the close, and two intradaily call auctions. The market is fully transparent, again with the exception of the hidden part of iceberg orders. Block trades may be negotiated outside the system. In this case, they are not reported as transactions in Xetra. Deutsche Börse AG also offers a block trading facility (Xetra XXL), an anonymous matching system with closed order book.

Designated sponsors (similar to the Euronext liquidity providers) stand ready to increase the liquidity for less liquid stocks. Finally, as in Euronext, volatility interruptions are triggered when a potential transaction price lies outside of a pre-determined interval.

Despite many similarities, there also differences between the trading systems. These concern the trading hours, the existence of intradaily call auctions, and the rule for cross and block trades alluded to above. Another potentially important point is that Xetra faces competition by the Frankfurt Stock Exchange (a floor-based exchange with a trading system similar to that of the NYSE) and several small regional exchanges.

There are many more designated sponsors in Xetra than there are liquidity providers in Euronext. This holds both with respect to the number of stocks with a sponsoring or liquidity provision agreement and the number of sponsors or liquidity providers per stock. The requirements for the designated sponsors in Xetra are defined by Deutsche Börse AG for groups of 
stocks. They are thus not subject to negotiation. Further, Deutsche Börse AG performs rankings of the sponsors and publishes the results in quarterly intervals. Euronext, on the other hand, does not specify the requirements for the liquidity providers to the same extent. Regular rankings are performed, but are not published. ${ }^{6}$

The price limits that trigger a volatility interruption are known to Euronext market participants. The respective limits are not known to traders in Xetra. Therefore, Xetra market participants are uncertain about whether a certain order will trigger a trading halt or not.

The minimum tick size is different between the two markets. It is always $€ 0.01$ in Xetra. ${ }^{7}$ In Euronext, on the other hand, it is $€ 0.01$ only for stocks trading at prices below $€ 50$. It increases to $€ 0.05$ for stocks with prices above $€ 50$, to $€ 0.1$ for stocks with prices above $€ 100$, and to $€ 0.5$ for stocks with prices above $€ 500$.

\section{Data and Methodology}

The data for our empirical analysis was provided by the exchanges. Both Deutsche Börse AG and Euronext provide CD-ROMs containing time-stamped data on bid and ask prices, transaction prices and trading volumes. Our sample covers the three months (65 trading days), May, June and July 2002. ${ }^{8}$

Using these data sets we create matched samples of 40 pairs of stocks where each pair consists of one French stock traded on Euronext Paris and one German stock traded in Xetra. We start by defining an initial sample of stocks from which the pairs are to be drawn. ${ }^{9}$ For

6 Euronext does, however, publish average spread and depth figures for instruments. This allows inferences about the performance of the liquidity providers.

7 There is an exception for stocks trading at prices below $€ 0.1$, a case which is irrelevant in our sample.

8 We screened the data set for errors by applying a set of filters. Quotes were deleted from the sample when either the bid or the ask price was non-positive, when the spread was negative, when the percentage quoted spread exceeded $10 \%$, and when a quoted price involved a price change since the previous quote of more than $10 \%$.

9 We exclude stocks that are not traded continuously. This is the case for some less liquid stocks. 
France, we choose the SFB 250, an index comprising the 250 largest stocks. For Germany we choose all constituent stocks of the DAX, the MDAX and the SDAX indices. Taken together, these indices comprise the 200 largest stocks.

The matched stocks should be as similar as possible with respect to those characteristics that determine the liquidity. Following the literature (e.g., Huang and Stoll, 1996; Bessembinder and Kauffman, 1997; Venkataraman, 2001) we match on market capitalization, trading volume, price level and volatility. Market capitalization, trading volume and the price level are calculated as daily averages over the sample period. Return volatility is the standard deviation of daily returns over the sample period.

One problem complicates the matching procedure. The turnover velocity (defined as the ratio of euro volume and market capitalization) is markedly different in the two markets. In our initial sample described above, the turnover velocity is $47.7 \%$ for the French stocks and 69.8\% for the German stocks (unweighted averages over the stocks). Consequently, matching on both criteria simultaneously yields poor results and may be inappropriate. Therefore we use a two-step procedure. In a first step we require that the relative difference in market capitalization, $M C$, does not exceed the threshold defined by

$$
\left|\frac{M C^{X E T R A}-M C^{E U R P}}{\left(M C^{X E T R A}+M C^{E U R P}\right) / 2}\right| \leq 0.75
$$

where the superscript (XETRA and EURP) relates to the market. This condition puts an upper bound on the difference in market capitalization. From the universe of all pairs of stock satisfying condition (1) we construct two matched samples. Matching criteria for the first sample are market capitalization, price and volatility. The criteria for the second sample are trading volume, price and volatility. In both cases the matching is performed by calculating the score 


$$
\sum_{i=1}^{3}\left(\frac{x_{i}^{\text {XETRA }}-x_{i}^{\text {EURP }}}{\left(x_{i}^{X E T R A}+x_{i}^{E U R P}\right) / 2}\right)^{2}
$$

where the $x_{i}, i=1,2,3$, correspond to the respective matching criteria. We then identify the best matching French stock (i.e., the one that yields the lowest score) for each of the German stocks and finally we select the 40 pairs with the lowest score for our final sample.

As noted in section 3, trading hours in Xetra are longer than those in Euronext. After the 17.30 auction, trading activity in Xetra slows down considerably. ${ }^{10}$ The main reason is that many institutional investors close their books at 7.30 Deutsche Börse AG has, subsequent to our sample period, shortened trading hours. The closing auction now takes place at 17.30, almost simultaneously with the closing auction in Euronext. In order not to let the different trading hours affect our results we restrict the analysis to those hours where both markets are open. Our analysis only considers data from the continuous trading sessions. We thus eliminate the data from the call auctions. The original data from Euronext Paris contains block trades (applications) whereas the Xetra data does not. We therefore exclude the block trades from our Euronext sample.

Table 2 presents descriptive statistics for the two samples resulting from our matching procedure. It also shows disaggregated results for quartiles sorted by market capitalization. Overall, the French and German stocks are reasonably similar with respect to market capitalization and price. Differences in volatility are small in magnitude but tend to be systematic. Return volatility for the German subsamples is lower overall and in all but one of the quartiles. The trading volume is similar only in the sample where it is used as a matching criterion. In the sample matched on market capitalization, the trading volume of the German stocks is markedly

10 Both the number of trades per hour and the trading volume per hour are about five times as large between 09.00 and 17.30 than they are between 17.30 and 20.00 . 
higher than the corresponding value for the French stocks. This is a consequence of the higher turnover velocity in Germany.

\section{Insert Table 2 about here}

Although the matching procedure arguably identified pairs of stocks that are reasonably similar, the remaining differences are large enough to potentially have an impact on liquidity. As a consequence, we will have to check whether any differences in liquidity that we may find are caused by a lack of control for relevant firm characteristics.

\section{Results}

Our first measure of market quality is the percentage quoted half spread, defined as

$$
s_{i, t}^{q}=100 \frac{a_{i, t}-b_{i, t}}{2 m_{i, t}}
$$

where $a, b$ and $m$ are the ask price, the bid price and the quote midpoint, respectively. The indices $i$ and $t$ denote the stock and time. We calculate a time-weighted average quoted half spread for each stock and each trading day. ${ }^{11}$ These daily averages are then used for the analysis. This procedure assures that each stock, irrespective of its trading volume, and each trading day, irrespective of the trading activity on that particular day, receive the same weight in the analysis.

Results are shown in Panel A of Table 3. The average quoted half spread in France is 0.55\% in the sample matched on market capitalization and $0.58 \%$ in the sample matched on volume. The corresponding figures for Germany are $0.45 \%$ and $0.50 \%$, respectively. The differences are significant in both cases, indicating that quoted spreads in Xetra are lower on average. Considering the median rather than the mean yields similar results. 
We next sort the sample stocks into four groups according to their market capitalization. The results are also shown in Panel A of Table 3. The result that quoted spreads in Xetra are lower than those in Euronext holds, with only two exceptions (the mean in the second group in the sample matched on market capitalization and the median in the fourth group in the sample matched on volume), through all groups.

\section{Insert Table 3 about here}

Transactions tend to cluster in periods in which spreads are low. Consequently, average effective spreads, which relate the transaction price to the quote midpoint in effect prior to the transaction, are expected to be lower than quoted spreads. The percentage effective half spread is defined as

$$
s_{i, t}^{e}=100 \frac{\left|p_{i, t}-m_{i, t}\right|}{m_{i, t}}
$$

Results for the effective half spread are shown in Panel B of Table 3. They are unanimously lower than the quoted spreads shown in Panel A. Effective half spreads in Xetra are, on average, $0.34 \%$ in the sample matched on market capitalization and $0.37 \%$ in the sample matched on volume. This is significantly less than the corresponding values of $0.434 \%$ and $0.427 \%$ we find for Euronext Paris. Results for the size groups confirm this finding. Effective spreads in Xetra are lower than those in Euronext with only one exception (the median in the fourth group in the sample matched on volume).

The results thus far suggest that both quoted and effective spreads are lower in Xetra. One way to gain further insights into the reasons for this pattern is to decompose the spread into its components. We follow the procedure used by Venkataraman (2001). The effective half

\footnotetext{
11 Using equally-weighted averages instead of time-weighted averages yields similar results.
} 
spread is decomposed into an adverse selection component (or price impact) $s^{a}$ and the realized half spread $s^{r}$. The latter has to cover order processing costs and contains any rents the suppliers of liquidity may earn. The two measures are defined as

$$
\begin{aligned}
& s_{i, t}^{a}=100 \cdot D_{i, t} \cdot \frac{\left(m_{i, t+\tau}-m_{i, t}\right)}{m_{i, t}} \\
& S_{i, t}^{r}=100 \cdot D_{i, t} \cdot \frac{\left(p_{i, t}-m_{i, t+\tau}\right)}{m_{i, t}}
\end{aligned}
$$

where $D_{i, t}$ is a trade indicator variable ( 1 for a buyer-initiated trade, -1 for a seller-initiated trade). ${ }^{12}$ The adverse selection component captures the price impact of a trade by measuring the change of the quote midpoint between the time of the transaction, $t$, and the midpoint at time $t+\tau$. The latter serves as a proxy for the true value of the stock at time $t+\tau$. We choose a value of 5 minutes for $\tau .{ }^{13}$ The realized half spread captures the revenue of the suppliers of liquidity net of losses to informed traders by relating the transaction price to the midpoint at time $t+\tau$.

The results are shown in Table 4. No clear pattern emerges for the adverse selection component. In the sample matched on market capitalization the difference in the adverse selection component is insignificant in the full sample while results for the size groups are mixed. In the sample matched on volume the adverse selection component is significantly smaller in the French market. Results for the size groups are again inconclusive. From this it can be concluded that differences in the adverse selection component do not explain the differences in spreads documented in Table 3.

Realized half spreads (shown in Panel B of Table 4) are significantly lower in Xetra. On average, realized spreads amount to $0.12 \%$ and $0.14 \%$ in Xetra as compared to $0.23 \%$ and $0.24 \%$

12 A transaction is classified as buyer-initiated [seller-initiated] if the price is above [below] the quote midpoint. 
in Euronext. This pattern holds through all size groups and irrespective of whether the mean or the median is considered. The result that realized spreads are rather high in the French market is consistent with Venkataraman (2001).

\section{Insert about here}

The descriptive statistics shown in Table 2 indicate that the matching procedure does not result in pairs of stocks that are equal with respect to all relevant variables. It is thus possible that the differences in spreads documented above are a consequence of different stock characteristics. To control for these effects we regress the difference in execution costs on the residual differences in a set of control variables. These are the log of market capitalization, the log of the price level, return volatility, the log of the number of transactions and the log of the average trade size. The model is

$$
\Delta s_{i, t}^{j}=\gamma_{0}+\gamma_{1} \Delta \ln \left(M C_{i}\right)+\gamma_{2} \Delta \ln \left(\bar{P}_{i, t}\right)+\gamma_{3} \Delta \sigma_{i, t}+\gamma_{4} \Delta \ln \left(\text { Notrans }_{i, t}\right)+\gamma_{5} \Delta \ln \left(\operatorname{Trdsize}_{i, t}\right)+\varepsilon_{i, t}(5)
$$

where

$\Delta s_{i, t}^{j}: \quad$ Difference in execution cost measure between French stock $i$ and the matched German stock on day $t . j \in q, e, a, r$ denotes the measure of execution costs (quoted and effective spread, adverse selection component and realized spread)

$\Delta \ln \left(M C_{i}\right): \quad$ Difference in the log of market capitalization between French stock $i$ and the matched German stock

13 Previous research (e.g. Huang and Stoll, 1996) implies that the results are insensitive to the choice of $\tau$. 
$\Delta \ln \left(\bar{P}_{i, t}\right): \quad$ Difference in the $\log$ of the price level between French stock $i$ and the matched German stock. $\bar{P}_{i}$ is the average transaction price of stock $i$ on day $t$.

$\Delta \sigma_{i, t}: \quad$ Difference in return volatility between French stock $i$ and the matched German stock. Volatility is measured by the standard deviation of midquote returns for stock $i$ on day $t$.

$\Delta \ln \left(\right.$ Notrans $\left._{i, t}\right):$ Difference in the log of the number of transactions on day $t$ between French stock $i$ and the matched German stock.

$\Delta \ln \left(\operatorname{Trdsize}_{i, t}\right):$ Difference in the log of the average trade size (measured in $€$ ) on day $t$ between French stock $i$ and the matched German stock.

Table 5 shows the results of GMM estimation. The independent variables have explanatory power in all regressions (although the $\mathrm{R}^{2}$ in the realized spread regression is rather low). This indicates that the matching procedure did not result in a perfectly matched sample. The difference between the quoted and effective spreads in Euronext and Xetra is significantly negatively related to the number of transactions, the average transaction size, the price level and market capitalization (although the coefficients of this variable are only significant in the sample matched on market capitalization). Spread differences are positively related to differences in volatility.

Differences in the adverse selection components are negatively related to differences in the price level and are positively related to differences in volatility and (in the sample matched on volume) also to differences in average trade size. Differences in realized spreads are negatively related to differences in the volume variables (number of trades and average trade size), market capitalization and the price level. 
If the explanatory variables explained the differences in the spread measures the constants should be zero. We find, however, that the constants in the quoted, effective and realized spread regressions are significantly positive. This indicates that spreads in Euronext are higher even after controlling for residual differences in market capitalization, price level, volatility and volume. The intercepts in the adverse selection component regression are insignificant. Thus, the higher spreads in Euronext are not explained by differences in the adverse selection component. Rather, the spread differences appear to be driven by differences in realized spreads.

\section{Insert Table 5 about here}

\section{Explaining the differences in the components of the spread}

Our results thus far indicate that spreads in Euronext are significantly higher than those in Xetra, and that these differences are driven by differences in the realized spreads. These differences may be due to the competitive environment or to the organization of the trading system.

We first turn to explanations based on differences in the trading systems. ${ }^{14}$ As outlined in section 3, and despite the similarity on a "macro level", there remain important differences in the way trading is organized on the two exchanges. We consider two differences that potentially have an impact on execution costs.

First, minimum tick sizes are different in Euronext and Xetra. The tick size is $€ 0.01$ for all stocks (except those trading at prices below €0.10) in Xetra. In Euronext, on the other hand, the minimum tick size is $€ 0.01$ for stocks trading at prices below $€ 50, € 0.05$ for stocks trading at prices between $€ 50$ and $€ 100$, $€ 0.10$ for stocks trading at prices between $€ 100$ and $€ 500$, 
and $€ 0.50$ for stocks trading at prices above $€ 500$. As smaller tick sizes have been reported to be associated with lower spreads (e.g., Ronen and Weaver, 2001), the larger minimum tick size is a possible explanation for the larger realized spreads in Euronext.

Second, most stocks in Xetra (outside the DAX 30 index) have one or more designated sponsors. In Euronext, the number of stocks with a liquidity supplier is significantly lower. To the extent that the existence of a liquidity provision agreement (i.e., the existence of a sponsor or liquidity provider) increases liquidity, this may be another explanation for the higher realized spreads in Euronext.

In order to control for the effect of these variables we include them as additional explanatory variables in regression (5). The augmented model is

$$
\begin{aligned}
\Delta s_{i, t}^{j}= & \gamma_{0}+\gamma_{1} \Delta \ln \left(M C_{i}\right)+\gamma_{2} \Delta \ln \left(\bar{P}_{i, t}\right)+\gamma_{3} \Delta \sigma_{i, t}+\gamma_{4} \Delta \ln \left(\text { Notrans }_{i, t}\right) \\
& +\gamma_{5} \Delta \ln \left(\text { Trdsize }_{i, t}\right)+\gamma_{6} L P_{i}+\gamma_{7} 100 \Delta \text { Re ltick }_{i, t}+\varepsilon_{i, t}
\end{aligned}
$$

where

$L P_{i}: \quad$ Dummy variable which takes on the value one when the German stock $i$ has a designated sponsor and its French counterpart does not have a liquidity provider. $^{15}$

$\Delta$ Reltick $_{i, t}: \quad$ The difference in the relative tick size on day $t$ between French stock $i$ and the matched German stock. The relative tick size is the tick size (1 cent for

14 The analysis in this section is related to previous research investigating into the impact of stock exchange reforms on market quality, e.g. Majnoni and Massa (2001).

15 There are three cases (two in the sample matched on market capitalization and one in the sample matched on volume) where the opposite occurs, i.e., there is a liquidity provider in Euronext but no designated sponsor in Xetra. Including an additional dummy variable capturing these cases does not change the results. 
all German stocks, 1,5 or 10 cents $^{16}$ for the French stocks) divided by the price level of the stock.

All other variables are as defined previously. We expect a positive sign for the two additional variables in the quoted, effective and realized spread regressions. The difference between the spread measure for the French stock and its German counterpart should be larger when only the German stock has a liquidity provision agreement, or when the tick size of the French stock is larger.

\section{Insert Table 6 about here}

The results are shown in Table 6. Comparing them to those reported in Table 5 reveals that the additional variables do not have much additional explanatory power, as is evidenced by only slightly increased $\mathrm{R}^{2} \mathrm{~s}$. The dummy variable for the liquidity provision agreements is insignificant. This indicates that the presence of a liquidity provider does not have a significant impact on liquidity. The coefficient on the tick size variable is, contrary to our expectations, significantly negative, implying that stocks with larger relative tick size have lower, rather than higher, spreads. ${ }^{17}$

The constants are still significantly positive for the quoted, effective and realized spread and are insignificant for the adverse selection component. This implies that neither differences in the tick size nor differences in the frequency of liquidity provision agreements explain the spread differences between Xetra and Euronext.

16 Our sample does not contain stocks with prices above $€ 500$. Consequently, there are no French stocks with a tick size of 50 cents.

17 We estimated an alternative specification where we replaced the relative tick size variable by two dummy variables which take on the value 1 for those French stocks with a minimum tick size of $€ 0.05$ and $€ 0.10$, respectively. The coefficients of the dummy variables are significantly negative. We do not have a good explanation for the negative coefficients of the tick size variables in both specifications. 
Another important difference between the French and the German equity market is the degree of domestic competition for order flow. Whereas there is no domestic competitor for Euronext, Xetra faces competition by the Frankfurt Stock Exchange and several regional exchanges. Notwithstanding the existence of competing trading venues, Xetra attains market shares exceeding 90\% for most DAX stocks. For less liquid stocks, however, Xetra market shares are much lower. ${ }^{18}$ We use the Xetra market share as a proxy for the degree of domestic competition for order flow. The lower the market share the more intense the competition.

There is one potential problem here. The Xetra market share is lower for less liquid stocks. The results in Table 3 indicate that Xetra enjoys a larger transaction cost advantage for less liquid stocks. Consequently, the market share variable may simply be picking up a firm size effect. ${ }^{19}$ Therefore, we control for firm size by including the average market capitalization of each pair of firms as an additional explanatory variable. This yields the model

$$
\begin{aligned}
\Delta s_{i, t}^{j}=\gamma_{0} & +\gamma_{1} \Delta \ln \left(M C_{i}\right)+\gamma_{2} \Delta \ln \left(\bar{P}_{i, t}\right)+\gamma_{3} \Delta \sigma_{i, t}+\gamma_{4} \Delta \ln \left(\text { Notrans }_{i, t}\right)+\gamma_{5} \Delta \ln \left(\text { Trdsize }_{i, t}\right)+\gamma_{6} L_{i} \\
& +\gamma_{7} 100 \Delta \operatorname{Re} P_{i t i c k}+\gamma_{8} M S_{i}^{\text {Xetra }}+\gamma_{9} \ln \left(\overline{M C}_{i, t}\right)+\varepsilon_{i, t}
\end{aligned}
$$

where

$M S_{i}^{\text {Xetra }}: \quad$ Xetra market share for German stock $i^{20}$

$\ln \left(\overline{M C}_{i, t}\right): \quad$ the $\log$ of the average market capitalization of the stock pair $i$

There is no clear prediction as to the sign of the market share coefficient. On the one hand, higher Xetra market share implies less competition and, consequently, might lead to higher spreads. The difference between spreads in Euronext and those in Xetra (our dependent vari-

18 The observation that Xetra market share is increasing in the liquidity of the stock is corroborated by high correlations between the Xetra market share on the one hand and market capitalization, trading volume and the number of transactions on the other hand.

19 We thank the anonymous referee for directing our attention to this point. 
able) should then be smaller for stocks with a high Xetra market share. In this case we would expect a negative coefficient. On the other hand, however, higher Xetra market share implies that liquidity is concentrated in one market place. This may lead to lower spreads in Xetra and, by implication, we should expect a positive coefficient in this case.

We expect a negative coefficient on the average market capitalization as spread differences are, as documeted in Table 3, larger for smaller firms. The results are shown in Table 7. Comparison with those in Table 5 and Table 6 reveals that most coefficients retain their sign and significance. A notable exception is the tick size variable which loses significance in all but one case. The firm size measure $\ln \left(\overline{M C}_{i, t}\right)$ enters significantly, with the coefficient being negative in the quoted, effective and realized spread regressions and positive in the adverse selection component regression. The coefficient on the market share variable is predominantly negative but is significant in only one case. This implies that, after controlling for firm size, the Xetra market share does not explain the differences in transaction costs. ${ }^{21}$

\section{Insert Table 7 about here}

In summary we find that, although the variables employed to capture differences in the trading systems and in the competitive environment do have explanatory power, they do not fully explain the differences in transaction costs between Xetra and Euronext.

20 The market shares are taken from the monthly Kassamarktstatistik published by Deutsche Börse AG. We use the average of the market shares for May, June and July 2002.

21 Battalio et al. (1997) find that spreads on the New York Stock Exchange are hardly affected by competitive pressure from the regional exchanges in Boston and Cincinnati. This result is consistent with ours, as we find that spreads in Xetra (measured relative to those in Euronext) are not affected by competitive pressure from the regional exchanges. Other papers analyzing the impact of competition on market quality include Taylor (2002) and Gresse (2006). 


\section{Summary and Conclusions}

In the present paper we compare execution costs in Euronext Paris to those in Xetra. Both are anonymous electronic limit order books. Though the two systems are similar, there are differences in detail. For example, minimum tick sizes and the degree to which designated market makers are involved in the trading process are different.

To control for different stock characteristics, we construct two matched samples of 40 pairs of stocks. The matching criteria are market capitalization, price level and return volatility for the first sample and trading volume, price level and volatility for the second sample. Results for both samples are similar. This indicates that the results are robust to the details of the matching procedure.

We use these samples to compare quoted and effective spreads, the adverse selection component of the spread, and the realized spread. Spreads generally tend to be lower in Xetra. This general finding is consistent with the results reported in Ellul (2002) who analyzes the predecessors of the current trading systems, i.e., IBIS and CAC.

Considering the components of the spread we find that there are no significant differences in adverse selection costs. The higher spreads in Euronext are thus due to high realized spreads. This result is consistent with Venkataraman (2001) who also documented that realized spreads in the French market are high.

We use a set of regressions to analyze whether these results are explained by differences in stock characteristics not eliminated by our matching procedure. The results of the regression analysis confirm the finding that execution costs are lower in Xetra. In an attempt to explain these differences we control for the differing number of liquidity provision agreements and differences in minimum tick size. Neither characteristic do not fully explains the larger execution costs in Euronext. The same is true for the degree of domestic competition for order flow 
in Germany. The question why realized spreads in Euronext are so high thus remains an open issue. 


\section{References}

Affleck-Graves, J., Hedge, S. P. and Miller, R. E., 'Trading mechanisms and the components of the bid-ask spread', Journal of Finance, Vol. 49, 1994, pp. 1471-1488.

Battalio, R., Greene, J. and Jennings, R., 'Do competing specialists and preferencing dealers affect market quality?’, Review of Financial Studies, Vol. 10, 1997, pp. 969-993.

Bessembinder, H. and Kauffman, H. M., 'A comparison of trade execution costs for NYSE and NASDAQ-listed stocks’, Journal of Financial and Quantitative Analysis, Vol. 32, 1996, pp. 287-310.

Davydoff, D., Gajewski, J.-F., Gresse, C. and Grillet-Aubert, L., ‘Trading cost analysis: a comparison of Euronext Paris and the London Stock Exchange’, Working Paper (IEM Finance, Université Paris XII, Université X, 2002).

De Jong, F., Nijman, T. and Roell, A.,'A comparison of the cost of trading french shares on the Paris Bourse and on SEAQ International', European Economic Review, Vol. 39, 1995, pp. 1277-1301.

Degryse, H., 'The Total Cost of Trading Belgian Shares: Brussels versus London', Discussion Paper No. 1581 (Centre for Economic Policy Research, London, 1997).

Di Noia, C., 'Competition and Integration Among Stock Exchanges in Europe: Network Effects, Implicit Mergers and Regulatory Considerations’, European Financial Management, Vol. 7, 2001, pp. 39-72.

Domowitz, I., Glen, J. and Madhavan, A.,'Liquidity, volatility, and equity trading costs across countries and over time’, International Finance, Vol. 4, 2001, pp. 221-255.

Ellul, A., 'The dominace of hybrid trading systems: an analysis of execution costs, market depth and competition’, Working Paper (Indiana University, 2002). 
Gajewski, J.-F. And Gresse, C., 'Trading cost analysis: a comparison of Euronext Paris and the London Stock Exchange’, Working Paper (Université Paris XII, Université X, 2004).

Gresse, C., 'The Effect of Crossing-Network Trading on Dealer Market's Bid-Ask Speads’, European Financial Management, Vol. 12, 2001, pp. 143-160.

Huang, R. D. and Stoll, H.R., 'Dealer versus auction markets: a paired comparison of execution costs on NASDAQ and the NYSE', Journal of Financial Economics, Vol. 41, 1996, pp. 313-357.

Jain, P., 'Institutional design and liquidity on stock exchanges’, Working Paper (Indiana University, 2001).

London Economics, 'Quantification of the macro-economic impact of integration of EU financial markets', Final Report to the European Commission, 2002.

Majnoni, G. and Massa, M., 'Stock Exchange Reforms and Market Efficiency: The Italian Evidence’, European Financial Management, Vol. 7, 2001, pp. 93-116.

Pagano, M. and Roell, A., 'Trading systems in european stock exchanges: current performance and policy options’, Economic Policy, Vol. 10, 1990, pp. 63-115.

Piwowar, M., 'Intermarket order flow and liquidity: a cross-sectional and time-series analysis of cross-listed securities on U.S. stock exchanges and Paris Bourse', Working paper (Pennsylvania State University, 1997).

Ronen, T. and Weaver, D., “"Teenies" Anyone?’, Journal of Financial Markets, Vol. 4, 2001, pp. 231-260.

Schmidt, H. and Iversen, P., 'Automating german equity trading: bid-ask spreads on competing systems’, Journal of Financial Services Research, Vol. 6, 1993, pp. 373-397. 
Swan, P. and Westerholm, J.,'The impact of market architectural features on world equity market performance: a structural equation approach', Working Paper (University of New South Wales, University of Sydney, 2004).

Taylor, N., 'Competition on the London Stock Exchange', European Financial Management, Vol. 8, 2001, pp. 399-420.

Venkataraman, K., 'Automated versus floor trading: an analysis of execution costs on the Paris and New York Exchanges’, Journal of Finance, Vol. 56, 2001, pp. 1445-1485. 
Table 1: The Trading Systems

\begin{tabular}{|c|c|c|}
\hline & Xetra & Euronext \\
\hline Nature of trading system & - $\quad$ Electronic open limit order book & - $\quad$ Electronic open limit order book \\
\hline $\begin{array}{c}\text { Trading mechanism by stock } \\
\text { groups }\end{array}$ & $\begin{array}{l}\text { - Liquid stocks: call auctions (open, intradaily, close) and con- } \\
\text { tinuous trading } \\
\text { - } \quad \text { Illiquid stocks: call auction }\end{array}$ & $\begin{array}{l}\text { - Liquid stocks: call auctions (open, close) and continuous trad- } \\
\text { ing } \\
\text { - } \quad \text { Less liquid stocks: two call auctions } \\
\text { - } \quad \text { Least liquid stocks: one call auction }\end{array}$ \\
\hline Call auctions & $\begin{array}{l}\text { - Pre-trading phase with closed book, allows entry and modifica- } \\
\text { tion of orders } \\
\text { - } \quad \text { Indicative prices are disseminated } \\
\text { - } \text { Order imbalance information provided for DAX stocks and } \\
\text { stocks with designated sponsors (see below) } \\
\text { - Price determination based on volume maximization, order im- } \\
\text { balance, reference price } \\
\text { - Random price determination time }\end{array}$ & $\begin{array}{l}\text { - Pre-trading phase with partially open ( } 5 \text { best bid and ask prices } \\
\text { and the respective quantities are given) book. allows entry and } \\
\text { modification of orders } \\
\text { - Indicative prices are disseminated } \\
\text { - Price determination based on volume maximization, order im- } \\
\text { balance, reference price } \\
\text { - Random price determination time }\end{array}$ \\
\hline Admissible order types & $\begin{array}{l}\text { - Market, limit, market-to-limit, stop orders } \\
\text { - Additional execution conditions admissible: immediate-or- } \\
\text { cancel, fill-or-kill } \\
\text { - Validity constraints: good-for-day, good-till-date, good-till- } \\
\text { cancelled (maximum validity } 90 \text { days) } \\
\text { - Admissible trading restrictions, e.g. auction only, opening only } \\
\text { - Iceberg orders: specify overall volume and peak volume; ice- } \\
\text { berg orders are not identified in the book; time stamp equal to } \\
\text { time at which peak appears on the screen }\end{array}$ & $\begin{array}{l}\text { - Market, Must-be-filled (the latter must be fully executed, only } \\
\text { one of these typed is admissible for a given instrument), limit, } \\
\text { market-to-limit, stop orders } \\
\text { - Additional execution conditions admissible: fill-and-kill, all-or- } \\
\text { none, minimum quantity (with fill-or-kill as special case) } \\
\text { - Validity constraints: good-for-day, good-till-date, good-till } \\
\text { cancelled (maximum validity } 365 \text { days) } \\
\text { - Iceberg orders: specify overall volume and peak volume; ice- } \\
\text { berg orders are not identified in the book; time stamp equal to } \\
\text { time at which peak appears on the screen } \\
\text { - Cross trades and block trades negotiated outside, but funnelled } \\
\text { through the system (and subject to price restrictions!) }\end{array}$ \\
\hline
\end{tabular}


Table 1 (continued)

\begin{tabular}{|c|c|c|}
\hline & Xetra & Euronext \\
\hline Priority rules & - $\quad$ Price, time (except hidden parts of iceberg orders) & - Price, time (except hidden parts of iceberg orders) \\
\hline Anonymity & 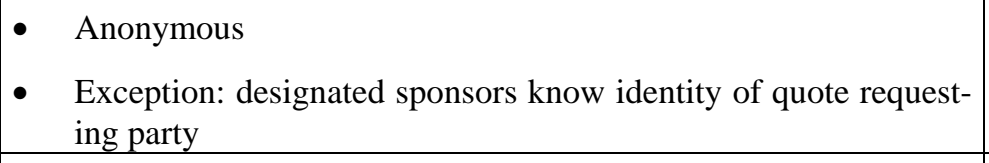 & $\begin{array}{l}\text { - Anonymous (since 2001; before: broker IDs appeared on the } \\
\text { screen) }\end{array}$ \\
\hline Minimum tick size & $\begin{array}{ll}\text { - } & € 0.01 \\
\text { - } & € 0.001 \text { for instruments with prices below } € 0.1\end{array}$ & $\begin{array}{ll}\text { - } & € 0.01 \text { if price }<€ 50 \\
\text { - } & € 0.05 \text { if } € 50 \leq \text { price }<€ 100 \\
\text { - } & € 0.10 \text { if } € 100 \leq \text { price }<€ 500 \\
\text { - } & € 0.50 \text { if price }>€ 500 \\
\end{array}$ \\
\hline Minimum order size & - 1 share & - 1 share \\
\hline
\end{tabular}


Table 1 (continued)

\begin{tabular}{|c|c|c|}
\hline & Xetra & Euronext \\
\hline
\end{tabular}


Table 1 (continued)

\begin{tabular}{|c|c|c|}
\hline & Xetra & Euronext \\
\hline Domestic parallel trading venues & $\begin{array}{l}\text { - Floor trading on the Frankfurt Stock Exchange and seven re- } \\
\text { gional exchanges } \\
\text { - } \quad \text { OTC trading } \\
\text { - } \quad \begin{array}{l}\text { Since September } 2002 \text { (after our sample period): Internalization } \\
\text { of orders through XetraBest }\end{array} \\
\end{array}$ & - $\quad$ No \\
\hline Circuit breakers & $\begin{array}{l}\text { - Volatility interruption if potential price outside pre-defined } \\
\text { range around reference price } 1 \text { (the last determined price) or } \\
\text { reference price } 2 \text { (last auction price) } \\
\text { - The width of the ranges are not disclosed to market participants } \\
\text { and are adapted to market conditions } \\
\text { - Market order interruption: when market orders exist that are not } \\
\text { executable } \\
\text { - Trading resumes with call auction } \\
\text { - } \quad \begin{array}{l}\text { Exchange can suspend trading in case of information events; } \\
\text { orders in the system are deleted }\end{array}\end{array}$ & $\begin{array}{l}\text { - Volatility interruption if potential price outside pre-defined } \\
\text { range around static reference price (in general the opening } \\
\text { price) or dynamic reference price (in general the last traded } \\
\text { price) } \\
\text { - Static price range }+/-10 \% \text {, dynamic price range }+/-2 \% \text { or }+/- \\
5 \% \text {, depending on instrument group } \\
\text { - Trading resumes with call auction } \\
\text { - Exchange can suspend trading in case of corporate events; or- } \\
\text { ders in the system are deleted }\end{array}$ \\
\hline Handling of block trades & $\begin{array}{l}\text { - } \quad \text { Specific block trading segment (Xetra XXL) } \\
\text { - Matching of orders at the Xetra quote midpoint (i.e., Xetra XXL } \\
\text { itself does not contribute to price discovery) } \\
\text { - } \quad \text { Anonymous, closed order book }\end{array}$ & $\begin{array}{l}\text { - Negotiated outside the order book } \\
\text { - In general, price constraints resulting from the status of the } \\
\text { book apply } \\
\text { - Trades are reported to Euronext and published there }\end{array}$ \\
\hline
\end{tabular}


Table 2: Sample Description

\section{Panel A: Descriptive statistics}

Panel A presents descriptive statistics for the full sample and for sub-samples formed according to market capitalization (using the average market capitalization of the pairs as sorting criterion). Market capitalization, trading volume and price level are measured as daily averages over the sample period. Return volatility is the standard deviation of daily returns over the sample period.

\begin{tabular}{|c|c|c|c|c|c|c|c|c|c|}
\hline & & \multicolumn{4}{|c|}{ Matching: cap., price, volatility } & \multicolumn{4}{|c|}{ Matching: volume, price, volatility } \\
\hline & & $\begin{array}{c}\text { cap. } \\
\text { (€ mio.) }\end{array}$ & $\begin{array}{l}\text { volume } \\
\text { (€ mio.) }\end{array}$ & $\begin{array}{c}\text { volatil- } \\
\text { ity }\end{array}$ & price & $\begin{array}{c}\text { cap. } \\
\text { (€ mio.) }\end{array}$ & $\begin{array}{l}\text { volume } \\
\text { (€ mio.) }\end{array}$ & $\begin{array}{c}\text { volatil- } \\
\text { ity }\end{array}$ & price \\
\hline full & FRA & $6,956.2$ & 812,501 & 0.0274 & 35.38 & 4965.7 & 429,259 & 0.0273 & 31.40 \\
\hline sample & GER & $6,876.9$ & 504,938 & 0.0263 & 34.46 & 4273.0 & 449,336 & 0.0254 & 29.84 \\
\hline \multirow{2}{*}{$1 \mathrm{st}$} & FRA & $24,630.1$ & $3,090,713$ & 0.0273 & 45.16 & 17188.0 & $1,551,317$ & 0.0256 & 45.29 \\
\hline & GER & $24,275.0$ & $1,862,368$ & 0.0261 & 44.90 & 14703.4 & $1,617,901$ & 0.0247 & 43.55 \\
\hline \multirow{2}{*}{ 2nd } & FRA & $2,458.4$ & 121,570 & 0.0264 & 31.73 & 2100.8 & 150,413 & 0.0321 & 32.4 \\
\hline & GER & $2,476.5$ & 131,937 & 0.0249 & 31.65 & 1897.2 & 165,031 & 0.0293 & 30.5 \\
\hline \multirow{2}{*}{ 3rd } & FRA & 623.9 & 32,565 & 0.0270 & 37.34 & 456.1 & 12,579 & 0.0256 & 27.9 \\
\hline & GER & 637.9 & 22,259 & 0.0275 & 33.18 & 359.5 & 11,553 & 0.0246 & 27.2 \\
\hline \multirow{2}{*}{ 4th } & FRA & 112.4 & 5,157 & 0.0287 & 27.29 & 118.0 & 2,727 & 0.0260 & 20.0 \\
\hline & GER & 118.3 & 3,186 & 0.0265 & 28.12 & 131.9 & 2,8589 & 0.0232 & 18.10 \\
\hline
\end{tabular}

Panel B: The sample stocks

\begin{tabular}{|c|c|c|c|c|}
\hline & \multicolumn{2}{|c|}{ Matching: cap., price, volatility } & \multicolumn{2}{|c|}{ Matching: volume, price, volatility } \\
\hline & France & Germany & France & Germany \\
\hline $1 \mathrm{st}$ & $\begin{array}{l}\text { Sanofi-Aventis, BNP Paribas, } \\
\text { L'Oreal. LVMH, Renault, } \\
\text { EADS, Schneider, Bouygues, } \\
\text { AGF Assurance Generale, } \\
\text { Arcelor }\end{array}$ & $\begin{array}{l}\text { Siemens, DaimlerChrysler, } \\
\text { Deutsche Bank., BMW, Volks- } \\
\text { wagen, Deutsche Post, Schering, } \\
\text { Metro., Altana., ThyssenKrupp }\end{array}$ & $\begin{array}{l}\text { BNP Paribas, Carrefour, } \\
\text { LVMH, Peugeot, EADS, } \\
\text { Bouygues, AGF Assurance } \\
\text { Generale, Arcelor, Pernod- } \\
\text { Ricard, Essilor. }\end{array}$ & $\begin{array}{l}\text { DaimlerChrysler, BMW, } \\
\text { Volkswagen, Schering, Com- } \\
\text { merzbank, Metro, Altana, } \\
\text { ThyssenKrupp, Henkel, } \\
\text { Deutsche Boerse }\end{array}$ \\
\hline 2nd & $\begin{array}{l}\text { Essilor, Valeo, M6-Metropole } \\
\text { TV, Air France-KLM, Euro- } \\
\text { next, Remy Cointreau, NRJ } \\
\text { Group, Clarins, SCOR, Zodiac }\end{array}$ & $\begin{array}{l}\text { Deutsche Börse, Heidelberger } \\
\text { Druckmaschinen, Karstadt } \\
\text { Quelle, Continental, MAN, } \\
\text { Fraport, Hochtief, Wella, Cela- } \\
\text { nese, Merck }\end{array}$ & $\begin{array}{l}\text { Dassault Systemes, Altran } \\
\text { Tech., BIC, Euronext, Remy } \\
\text { Cointreau, NRJ Group, Zodi- } \\
\text { ac, Euler Hermes, Fimalac, } \\
\text { Ingenico }\end{array}$ & $\begin{array}{l}\text { Epcos, MLP, Heidelberger } \\
\text { Druckmaschinen, Continental, } \\
\text { Fraport, Hochtief, Merck, } \\
\text { Fielmann, Stada, Jenoptik }\end{array}$ \\
\hline 3rd & $\begin{array}{l}\text { Neopost, Rodriguez Group, } \\
\text { Teleperformance, Ingenico, } \\
\text { Vallourec, Cegedim, Union } \\
\text { Financiere, Nexans, Carbone- } \\
\text { Lorraine, Orpea }\end{array}$ & $\begin{array}{l}\text { AVA, Puma, Jenoptik, Hugo } \\
\text { Boss, Mannheimer, Beru, GfK, } \\
\text { SGL Carbon, Tecis Holding, } \\
\text { Dyckerhoff }\end{array}$ & $\begin{array}{l}\text { Beneteau, Generale de Sante, } \\
\text { April Group, Nexans, Compa- } \\
\text { gnie Generale de Geophysi- } \\
\text { que, Hyparlo, Norbert Den- } \\
\text { tressangle, Kaufman et Broad, } \\
\text { Carbone-Lorraine, Groupe } \\
\text { Sterica }\end{array}$ & $\begin{array}{l}\text { Beru, IWKA, Dyckerhoff, SGL } \\
\text { Carbon, Rhoen-Klinikum, } \\
\text { Hornbach Baumarkt, DIS, } \\
\text { Koenig + Bauer, Zapf Creation, } \\
\text { Wedeco }\end{array}$ \\
\hline 4th & $\begin{array}{l}\text { Etam Developpement, Gifi, } \\
\text { Inter Parfums, Laurent Perrier, } \\
\text { Cegid, Flo (Groupe), Groupe } \\
\text { Open, Lucia, Maison France } \\
\text { Confort, Toupargel Agrigel }\end{array}$ & $\begin{array}{l}\text { Wedeco, Loewe, Krones, Zapf } \\
\text { Creation, Fuchs Petrolub, Esca- } \\
\text { da, Cundomi, A.S.Creation, } \\
\text { Gaphit Kropfmuehl, STO }\end{array}$ & $\begin{array}{l}\text { Haulotte Group, Fleury Mi- } \\
\text { chon, Rubis, Ales Groupe, } \\
\text { Bail Investissement Fonciere, } \\
\text { Maison France Confort, SII, } \\
\text { Lucia, Toupargel Agrigel, CS } \\
\text { Communication \& Systems }\end{array}$ & $\begin{array}{l}\text { Gerry Weber International, } \\
\text { Derr, Edscha, Loewe, Condo- } \\
\text { mi, Escada, STO, Biotest, A.S. } \\
\text { Creation, Graphit Kropfmuehl }\end{array}$ \\
\hline
\end{tabular}


Table 3: Comparison of Bid-Ask Spreads

\section{Panel A: Quoted Half Spreads - Time-Weighted}

This panel shows average quoted half spreads for the sample stocks. The quoted half spread is defined as

$$
s_{i, t}^{q}=100 \frac{a_{i, t}-b_{i, t}}{2 m_{i, t}} .
$$

We calculate an average quoted half spread for each stock and each trading days. The figures in the table are based on these daily averages. The first line shows mean and median values for the full sample. Lines 2 through 4 report values for three groups of stocks sorted by market capitalization. The test statistics are for a t-test for the equality of the means and a Wilcoxon test for the equality of the medians, respectively.

\begin{tabular}{|c|c|c|c|c|c|c|c|}
\hline & & \multicolumn{3}{|c|}{ Matching: cap., price, volatility } & \multicolumn{3}{|c|}{ Matching: volume, price, volatility } \\
\hline & & FRA & GER & $\begin{array}{c}\text { test statis- } \\
\text { tic }\end{array}$ & FRA & GER & $\begin{array}{c}\text { test statis- } \\
\text { tic }\end{array}$ \\
\hline \multirow{2}{*}{ full sample } & mean & 0.5461 & 0.4540 & 5.29 & 0.5789 & 0.5005 & 4.33 \\
\hline & median & 0.2817 & 0.2428 & 5.53 & 0.3188 & 0.3114 & 3.02 \\
\hline \multirow{2}{*}{$1 \mathrm{st}$} & mean & 0.0893 & 0.0709 & 9.38 & 0.0922 & 0.0804 & 8.12 \\
\hline & median & 0.0800 & 0.0607 & 11.28 & 0.0864 & 0.0714 & 9.31 \\
\hline \multirow{2}{*}{ 2nd } & mean & 0.2980 & 0.3249 & 1.39 & 0.3587 & 0.2698 & 7.07 \\
\hline & median & 0.2306 & 0.1875 & 5.45 & 0.2778 & 0.2207 & 5.58 \\
\hline \multirow{2}{*}{ 3rd } & mean & 0.5251 & 0.4480 & 3.52 & 0.6728 & 0.5841 & 3.56 \\
\hline & median & 0.3689 & 0.3491 & 1.87 & 0.5261 & 0.4972 & 2.18 \\
\hline \multirow{2}{*}{ 4th } & mean & 1.3057 & 0.9962 & 6.72 & 1.2209 & 1.1016 & 2.30 \\
\hline & median & 1.1026 & 0.8077 & 7.62 & 0.9181 & 0.9408 & 0.13 \\
\hline
\end{tabular}

\section{Panel B: Effective Half Spreads}

This panel shows average effective half spreads for the sample stocks. The effective half spread is defined as

$$
s_{i, t}^{e}=100 \frac{\left|p_{i, t}-m_{i, t}\right|}{m_{i, t}} .
$$

\begin{tabular}{|c|c|c|c|c|c|c|c|}
\hline & & \multicolumn{3}{|c|}{ Matching: cap., price, volatility } & \multicolumn{3}{|c|}{ Matching: volume, price, volatility } \\
\hline & & FRA & GER & $\begin{array}{c}\text { test statis- } \\
\text { tic }\end{array}$ & FRA & GER & $\begin{array}{c}\text { test statis- } \\
\text { tic }\end{array}$ \\
\hline \multirow{2}{*}{ full sample } & mean & 0.4335 & 0.3373 & 6.92 & 0.4273 & 0.3737 & 3.97 \\
\hline & median & 0.2447 & 0.1867 & 7.28 & 0.2694 & 0.2314 & 3.61 \\
\hline \multirow{2}{*}{$1 \mathrm{st}$} & mean & 0.0807 & 0.0688 & 6.84 & 0.0887 & 0.0752 & 6.55 \\
\hline & median & 0.0722 & 0.0603 & 9.84 & 0.0772 & 0.0658 & 8.53 \\
\hline \multirow{2}{*}{ 2nd } & mean & 0.2619 & 0.2521 & 0.62 & 0.3253 & 0.2487 & 6.46 \\
\hline & median & 0.2195 & 0.1521 & 7.69 & 0.2533 & 0.2023 & 6.01 \\
\hline \multirow{2}{*}{ 3rd } & mean & 0.5080 & 0.3906 & 5.22 & 0.5634 & 0.4780 & 4.17 \\
\hline & median & 0.3703 & 0.3100 & 1.08 & 0.4516 & 0.4157 & 3.27 \\
\hline \multirow{2}{*}{ 4th } & mean & 1.0780 & 0.7702 & 7.67 & 0.9200 & 0.8841 & 0.77 \\
\hline & median & 0.9181 & 0.6570 & 7.85 & 0.6561 & 0.7756 & 2.25 \\
\hline
\end{tabular}

The procedures and the structure of the table are as in Panel A. 


\section{Table 4: The Components of the Bid-Ask Spread}

\section{Panel A: Adverse-Selection Component}

This panel shows the adverse selection component of the spread for the sample stocks. The effective half spread is decomposed into an adverse selection component (or price impact) $s^{a}$ and the realized half spread $s^{r}$. The two measures are defined as

$$
s_{i, t}^{a}=100 \cdot D_{i, t} \cdot \frac{\left(m_{i, t+\tau}-m_{i, t}\right)}{m_{i, t}}, s_{i, t}^{r}=100 \cdot D_{i, t} \cdot \frac{\left(p_{i, t}-m_{i, t+\tau}\right)}{m_{i, t}}
$$

where $D_{i, t}$ is a trade indicator variable ( 1 for a buyer-initiated trade, -1 for a seller-initiated trade). The adverse selection component captures the price impact of a trade by measuring the change of the quote midpoint between the time of the transaction, $t$, and the midpoint at time $t+\tau$. The latter serves as a proxy for the true value of the stock at time $t+\tau$. We choose a value of 5 minutes for $\tau$. The first line of the table shows mean and median values for the full sample. Lines 2 through 4 report values for three groups of stocks sorted by market capitalization. The test statistics are for a t-test for the equality of the means and a Wilcoxon test for the equality of the medians, respectively.

\begin{tabular}{cccccccc}
\hline & & \multicolumn{2}{c}{ Matching: cap., price, volatility } & \multicolumn{2}{c}{ Matching: volume, price, volatility } \\
\cline { 3 - 7 } & & FRA & GER & $\begin{array}{c}\text { test statis- } \\
\text { tic }\end{array}$ & FRA & GER & $\begin{array}{c}\text { test statis- } \\
\text { tic }\end{array}$ \\
\cline { 3 - 7 } full sample & mean & 0.1987 & 0.2139 & 1.50 & 0.1899 & 0.2316 & 4.26 \\
& median & 0.1042 & 0.0971 & 1.21 & 0.1067 & 0.1207 & 4.16 \\
1st & mean & 0.0708 & 0.0625 & 4.14 & 0.0722 & 0.0669 & 2.47 \\
& median & 0.0625 & 0.0536 & 4.55 & 0.0632 & 0.0572 & 2.33 \\
\multirow{2}{*}{ 2nd } & mean & 0.1414 & 0.1754 & 2.59 & 0.1638 & 0.1672 & 0.42 \\
& median & 0.1113 & 0.0937 & 2.26 & 0.1303 & 0.1285 & 0.34 \\
3rd & mean & 0.2417 & 0.2289 & 0.77 & 0.2334 & 0.2944 & 3.38 \\
& median & 0.1486 & 0.1597 & 0.24 & 0.1502 & 0.2287 & 5.28 \\
4th & mean & 0.4050 & 0.4638 & 1.54 & 0.3518 & 0.4987 & 3.59 \\
& median & 0.2654 & 0.3195 & 2.77 & 0.1835 & 0.3451 & 4.95 \\
\hline
\end{tabular}

\section{Panel B: Realized Half Spreads}

This panel shows the realized half spread for the sample stocks. See the legend for Panel A for details.

\begin{tabular}{cccccccc}
\hline & & \multicolumn{2}{c}{ Matching: cap., price, volatility } & \multicolumn{2}{c}{ Matching: volume, price, volatility } \\
\cline { 3 - 8 } & & FRA & GER & $\begin{array}{c}\text { test statis- } \\
\text { tic }\end{array}$ & FRA & GER & \multicolumn{2}{c}{$\begin{array}{c}\text { test statis- } \\
\text { tic }\end{array}$} \\
\hline \multirow{2}{*}{ full sample } & mean & 0.2348 & 0.1235 & 9.36 & 0.2374 & 0.1421 & 8.06 \\
& median & 0.0924 & 0.0417 & 11.23 & 0.1116 & 0.0488 & 10.12 \\
1st & mean & 0.0098 & 0.0062 & 2.77 & 0.0164 & 0.0082 & 5.35 \\
& median & 0.0116 & 0.0046 & 4.48 & 0.0162 & 0.0061 & 6.26 \\
\multirow{2}{*}{ 2nd } & mean & 0.1206 & 0.0767 & 4.75 & 0.1615 & 0.0815 & 7.50 \\
& median & 0.0873 & 0.0427 & 10.00 & 0.1151 & 0.0551 & 8.24 \\
3rd & mean & 0.2662 & 0.1617 & 5.33 & 0.3300 & 0.1836 & 8.01 \\
& median & 0.1841 & 0.1015 & 8.23 & 0.2510 & 0.1549 & 9.04 \\
4th & mean & 0.6730 & 0.3064 & 8.00 & 0.5682 & 0.3853 & 3.60 \\
& median & 0.5360 & 0.2597 & 9.83 & 0.3412 & 0.3279 & 2.53 \\
\hline
\end{tabular}




\section{Table 5: Regression results}

The table reports the results of the regression

$$
\Delta s_{i, t}^{j}=\gamma_{0}+\gamma_{1} \Delta \ln \left(M C_{i}\right)+\gamma_{2} \Delta \ln \left(\bar{P}_{i, t}\right)+\gamma_{3} \Delta \sigma_{i, t}+\gamma_{4} \Delta \ln \left(\text { Notrans }_{i, t}\right)+\gamma_{5} \Delta \ln \left(\operatorname{Trdsize}_{i, t}\right)+\varepsilon_{i, t}
$$

$\Delta s_{i, t}^{j}$ is the difference in the execution cost measure between French stock i and the matched German stock on day t. $j \in q, e, a, r$ denotes the measure of execution costs (quoted and effective spread, adverse selection component and realized spread). $\Delta \ln \left(M C_{i}\right)$ is the difference in the log of market capitalization between French stock $\mathrm{i}$ and the matched German stock. $\Delta \ln \left(\bar{P}_{i, t}\right)$ is the difference in the log of the price; $\bar{P}_{i, t}$ is the average transaction price of stock $i$ on day $t . \Delta \sigma_{i, t}$ is the difference in return volatility, measured by the standard deviation of midquote returns on day $t . \Delta \ln \left(\right.$ Notrans $\left._{i, t}\right)$ is the difference in the log of the number of transactions for stock pair $i$ on day $t$ and $\Delta \ln \left(\right.$ Trdsize $\left._{\mathrm{i}, \mathrm{t}}\right)$ is the difference in the $\log$ of the average trade size (in $€$ ). The t-values in parentheses are based on GMM estimation.

\begin{tabular}{|c|c|c|c|c|c|c|c|c|}
\hline & \multicolumn{4}{|c|}{ Matching: cap., price, volatility } & \multicolumn{4}{|c|}{ Matching: volume, price, volatility } \\
\hline & $\Delta \mathrm{s}_{\mathrm{i}, \mathrm{t}}^{\mathrm{q}}$ & $\Delta \mathrm{s}_{\mathrm{i}, \mathrm{e}}^{\mathrm{e}}$ & $\Delta \mathrm{s}_{\mathrm{i}, \mathrm{t}}^{\mathrm{a}}$ & $\Delta s_{i, t}^{r}$ & $\Delta s_{\mathrm{i}, \mathrm{t}}^{\mathrm{q}}$ & $\Delta \mathrm{s}_{\mathrm{i}, \mathrm{t}}^{\mathrm{e}}$ & $\Delta \mathrm{s}_{\mathrm{i}, \mathrm{t}}^{\mathrm{a}}$ & $\Delta \mathrm{s}_{\mathrm{i}, \mathrm{t}}^{\mathrm{r}}$ \\
\hline \multirow{2}{*}{ constant } & 0.1275 & 0.0926 & -0.0021 & 0.0946 & 0.1475 & 0.1077 & -0.0011 & 0.1088 \\
\hline & $(9.05)$ & (7.78) & $(-0.20)$ & (6.14) & (8.79) & (6.88) & $(-0.12)$ & (6.16) \\
\hline \multirow{2}{*}{$\Delta \ln \left(\mathrm{MC}_{\mathrm{i}}\right)$} & -0.2902 & -0.2887 & -0.0584 & -0.2303 & -0.0408 & -0.0399 & 0.0087 & -0.0486 \\
\hline & $(-3.62)$ & $(-4.26)$ & $(-1.02)$ & $(-2.83)$ & $(-1.00)$ & $(-1.00)$ & $(0.37)$ & $(-1.19)$ \\
\hline \multirow{2}{*}{$\Delta \ln \left(\overline{\mathrm{P}}_{\mathrm{i}, \mathrm{t}}\right)$} & -0.3667 & -0.2963 & -0.1856 & -0.1107 & -0.2432 & -0.2136 & -0.1229 & -0.0907 \\
\hline & $(-3.73)$ & $(-3.02)$ & $(-2.31)$ & $(-1.12)$ & $(-6.12)$ & $(-6.08)$ & $(-3.16)$ & $(-2.15)$ \\
\hline \multirow{2}{*}{$\Delta \ln \left(\sigma_{\mathrm{i}, \mathrm{t}}\right)$} & 0.8552 & 0.7499 & 0.9534 & -0.2034 & 0.8000 & 0.6264 & 0.7732 & -0.1469 \\
\hline & $(4.87)$ & $(6.00)$ & $(5.86)$ & $(-1.74)$ & $(3.82)$ & $(4.96)$ & $(4.36)$ & $(-1.02)$ \\
\hline \multirow{2}{*}{$\Delta \ln \left(\right.$ Notrans $\left._{\mathrm{i}, \mathrm{t}}\right)$} & -0.0808 & -0.0660 & 0.0047 & -0.0707 & -0.0878 & -0.0604 & 0.0103 & -0.0707 \\
\hline & $(-7.54)$ & $(-5.95)$ & $(0.53)$ & $(-5.56)$ & $(-6.93)$ & $(-5.17)$ & $(1.12)$ & $(-4.92)$ \\
\hline \multirow{2}{*}{$\Delta \ln \left(\operatorname{Trdsize}_{\mathrm{i}, \mathrm{t}}\right)$} & -0.0770 & -0.0827 & 0.0049 & -0.0876 & -0.0524 & -0.0468 & 0.0368 & -0.0836 \\
\hline & $(-6.27)$ & $(-6.41)$ & $(0.37)$ & $(-4.96)$ & $(-4.18)$ & $(-3.42)$ & (3.68) & $(-5.08)$ \\
\hline $\mathrm{R}^{2}$ & 0.3724 & 0.2934 & 0.2422 & 0.0812 & 0.2345 & 0.1737 & 0.1639 & 0.0598 \\
\hline
\end{tabular}




\section{Table 6: Explaining transaction cost differences}

The table reports the results of the regression

$$
\begin{aligned}
\Delta s_{i, t}^{j}=\gamma_{0}+ & \gamma_{1} \Delta \ln \left(M C_{i}\right)+\gamma_{2} \Delta \ln \left(\bar{P}_{i, t}\right)+\gamma_{3} \Delta \sigma_{i, t}+\gamma_{4} \Delta \ln \left(\text { Notrans }_{i, t}\right)+\gamma_{5} \Delta \ln \left(\operatorname{Trdsize}_{i, t}\right)+\gamma_{6} L_{i} \\
& +\gamma_{7} 100 \Delta\left(\text { Reltick }_{\mathrm{i}, \mathrm{t}}\right)+\varepsilon_{i, t}
\end{aligned}
$$

$\Delta s_{i, t}^{j}$ is the difference in the execution cost measure between French stock i and the matched German stock on day t. $j \in q, e, a, r$ denotes the measure of execution costs (quoted and effective spread, adverse selection component and realized spread). $\Delta \ln \left(M C_{i}\right)$ is the difference in the log of market capitalization between French stock $\mathrm{i}$ and the matched German stock. $\Delta \ln \left(\overline{\mathrm{P}}_{\mathrm{i}, \mathrm{t}}\right)$ is the difference in the log of the price; $\bar{P}_{i, t}$ is the average transaction price of stock $i$ on day $t . \Delta \sigma_{i, t}$ is the difference in return volatility, measured by the standard deviation of midquote returns on day t. $\Delta \ln \left(\right.$ Notrans $\left._{i, t}\right)$ is the difference in the number of transactions for stock pair $i$ on day $t$ and $\Delta \ln \left(\operatorname{Trdsize}_{\mathrm{i}, \mathrm{t}}\right)$ is the difference in the log of the average trade size (in $€$ ). $\mathrm{LP}_{\mathrm{i}, \mathrm{t}}$ is a dummy variable which takes on the value 1 when the German stock, but not its French counterpart, has a liquidity provider. $\Delta \ln \left(\right.$ Reltick $\left._{\mathrm{i}, \mathrm{t}}\right)$ is the difference in the log of the relative tick size. The t-values in parentheses are based on GMM estimation.

\begin{tabular}{ccccccccc}
\hline & \multicolumn{3}{c}{ Matching: cap., price, volatility } & \multicolumn{4}{c}{ Matching: volume, price, volatility } \\
\cline { 2 - 9 } & $\Delta \mathrm{s}_{\mathrm{i}, \mathrm{t}}^{\mathrm{q}}$ & $\Delta \mathrm{s}_{\mathrm{i}, \mathrm{t}}^{\mathrm{e}}$ & $\Delta \mathrm{s}_{\mathrm{i}, \mathrm{t}}^{\mathrm{a}}$ & $\Delta \mathrm{s}_{\mathrm{i}, \mathrm{t}}^{\mathrm{r}}$ & $\Delta \mathrm{s}_{\mathrm{i}, \mathrm{t}}^{\mathrm{q}}$ & $\Delta \mathrm{s}_{\mathrm{i}, \mathrm{t}}^{\mathrm{e}}$ & $\Delta \mathrm{s}_{\mathrm{i}, \mathrm{t}}^{\mathrm{a}}$ & $\Delta \mathrm{s}_{\mathrm{i}, \mathrm{t}}^{\mathrm{r}}$ \\
\hline \multirow{2}{*}{ constant } & 0.1461 & 0.1096 & -0.0104 & 0.1201 & 0.1731 & 0.1311 & 0.0118 & 0.1193 \\
& $(7.14)$ & $(6.06)$ & $(-0.68)$ & $(5.30)$ & $(6.79)$ & $(5.30)$ & $(0.86)$ & $(4.53)$ \\
& -0.2408 & -0.2462 & -0.0788 & -0.1674 & -0.0288 & -0.0317 & 0.0094 & -0.0411 \\
$\Delta \ln \left(\mathrm{MC}_{\mathrm{i}}\right)$ & $(-3.05)$ & $(-3.81)$ & $(-1.38)$ & $(-2.08)$ & $(-0.71)$ & $(-0.80)$ & $(0.39)$ & $(-1.01)$ \\
& -0.3939 & -0.3202 & -0.1740 & -0.1462 & -0.2627 & -0.2269 & -0.1215 & -0.1053 \\
$\Delta \ln \left(\overline{\mathrm{P}}_{\mathrm{i}, \mathrm{t}}\right)$ & $(-3.86)$ & $(-3.20)$ & $(-2.18)$ & $(-1.47)$ & $(-6.92)$ & $(-6.63)$ & $(-3.13)$ & $(-2.52)$ \\
& 0.8583 & -0.7509 & 0.9529 & -0.2020 & 0.7952 & 0.6214 & 0.7712 & -0.1498 \\
$\Delta \ln \left(\sigma_{\mathrm{i}, \mathrm{t}}\right)$ & $(4.91)$ & $(6.07)$ & $(5.84)$ & $(-1.72)$ & $(3.82)$ & $(4.95)$ & $(4.35)$ & $(-1.02)$ \\
$\Delta \ln \left(\right.$ Notrans $\left._{\mathrm{i}, \mathrm{t}}\right)$ & -0.0888 & -0.0730 & 0.0080 & -0.0810 & -0.0913 & -0.0625 & 0.0116 & -0.0740 \\
& $-(-7.91)$ & $(-6.27)$ & $(0.80)$ & $(-5.77)$ & $(-6.97)$ & $(-5.39)$ & $(1.23)$ & $(-5.16)$ \\
$\ln \left(\operatorname{Trdsize}_{\mathrm{i}, \mathrm{t}}\right)$ & -0.0771 & -0.0829 & 0.0050 & -0.0880 & -0.0475 & -0.0427 & 0.0376 & -0.804 \\
& $(-6.22)$ & $(-6.37)$ & $(0.39)$ & $(-5.00)$ & $(-4.06)$ & $(-3.29)$ & $(3.79)$ & $(5.02)$ \\
$\mathrm{LP}_{\mathrm{i}, \mathrm{t}}$ & 0.0139 & 0.0100 & 0.0043 & 0.0143 & -0.0086 & -0.0153 & -0.0251 & 0.0098 \\
& $(0.46)$ & $(0.38)$ & $(-0.20)$ & $(0.44)$ & $(-0.28)$ & $(-0.54)$ & $(-1.37)$ & $(0.34)$ \\
$100 \Delta \ln \left(\right.$ Reltick $\left._{\mathrm{i}, \mathrm{t}}\right)$ & -1.2802 & -1.1162 & 0.5351 & -1.6513 & -1.9910 & -1.5143 & -0.2469 & -1.2674 \\
& $(-2.97)$ & $(-2.88)$ & $(-1.97)$ & $(-3.64)$ & $(-3.91)$ & $(-3.54)$ & $(-0.90)$ & $(-2.82)$ \\
$\mathrm{R}^{2}$ & 0.3778 & 0.2980 & 0.2435 & 0.0899 & 0.2442 & 0.1804 & 0.1648 & 0.0641 \\
\hline
\end{tabular}




\section{Table 7: Domestic Competition}

The table reports the results of the regression

$$
\begin{aligned}
\Delta s_{i, t}^{j}=\gamma_{0}+ & \gamma_{1} \Delta \ln \left(M C_{i}\right)+\gamma_{2} \Delta \ln \left(\bar{P}_{i, t}\right)+\gamma_{3} \Delta \sigma_{i, t}+\gamma_{4} \Delta \ln \left(\text { Notrans }_{i, t}\right)++\gamma_{5} \Delta \ln \left(\text { Trdsize }_{i, t}\right)+\gamma_{6} L_{i} \\
& +\gamma_{7} 100 \Delta\left(\text { Reltick }_{\mathrm{i}, \mathrm{t}}\right)+\gamma_{8} M S_{i}^{\text {Xetra }}+\gamma_{9} \ln \left(\overline{M C_{i}}\right)+\varepsilon_{i, t}
\end{aligned}
$$

$\Delta s_{i, t}^{j}$ is the difference in the execution cost measure between French stock i and the matched German stock on day t. $j \in q, e, a, r$ denotes the measure of execution costs (quoted and effective spread, adverse selection component and realized spread). $\Delta \ln \left(M C_{i}\right)$ is the difference in the log of market capitalization between French stock $\mathrm{i}$ and the matched German stock. $\Delta \ln \left(\overline{\mathrm{P}}_{\mathrm{i}, \mathrm{t}}\right)$ is the difference in the log of the price; $\bar{P}_{i, t}$ is the average transaction price of stock $i$ on day $t . \Delta \sigma_{i, t}$ is the difference in return volatility, measured by the standard deviation of midquote returns on day $t . \Delta \ln \left(\right.$ Notrans $\left._{i, t}\right)$ is the difference in the number of transactions for stock pair $i$ on day $t$ and $\Delta \ln \left(\operatorname{Trdsize}_{\mathrm{i}, \mathrm{t}}\right)$ is the difference in the log of the average trade size (in $€$ ). $\mathrm{LP}_{\mathrm{i}, \mathrm{t}}$ is a dummy variable which takes on the value 1 when the German stock, but not its French counterpart, has a liquidity provider. $\Delta \ln \left(\right.$ Reltick $\left._{\mathrm{i}, \mathrm{t}}\right)$ is the difference in the $\log$ of the relative tick size. $M S_{i}^{\text {Xetra }}$ is the Xetra market share for German stock $i . \ln \left(\overline{M C_{i}}\right)$ is the log of the average market capitalization of the stock pair $i$. The t-values in parentheses are based on GMM estimation.

\begin{tabular}{ccccccccc}
\hline & \multicolumn{3}{c}{ Matching: cap., price, volatility } & \multicolumn{3}{c}{ Matching: volume, price, volatility } \\
\cline { 2 - 9 } & $\Delta \mathrm{s}_{\mathrm{i}, \mathrm{t}}^{\mathrm{q}}$ & $\Delta \mathrm{s}_{\mathrm{i}, \mathrm{t}}^{\mathrm{e}}$ & $\Delta \mathrm{s}_{\mathrm{i}, \mathrm{t}}^{\mathrm{a}}$ & $\Delta \mathrm{s}_{\mathrm{i}, \mathrm{t}}^{\mathrm{r}}$ & $\Delta \mathrm{s}_{\mathrm{i}, \mathrm{t}}^{\mathrm{q}}$ & $\Delta \mathrm{s}_{\mathrm{i}, \mathrm{t}}^{\mathrm{e}}$ & $\Delta \mathrm{s}_{\mathrm{i}, \mathrm{t}}^{\mathrm{a}}$ & $\Delta \mathrm{s}_{\mathrm{i}, \mathrm{t}}^{\mathrm{r}}$ \\
\hline \multirow{2}{*}{ constant } & 0.6078 & 0.4536 & -0.1200 & 0.5736 & 0.7031 & 0.4761 & -0.0781 & 0.5542 \\
& $(7.39)$ & $(6.19)$ & $(-1.54)$ & $(5.67)$ & $(6.30)$ & $(4.85)$ & $(-1.02)$ & $(4.77)$ \\
$\Delta \ln \left(\mathrm{MC}_{\mathrm{i}}\right)$ & -0.1509 & -0.1678 & -0.1140 & -0.0538 & -0.0090 & -0.0202 & -0.0007 & -0.0195 \\
& $(-2.17)$ & $(-2.95)$ & $(-(2.01)$ & $(-0.80)$ & $(-0.24)$ & $(-0.53)$ & $(-0.03)$ & $(-0.50)$ \\
$\Delta \ln \left(\overline{\mathrm{P}}_{\mathrm{i}, \mathrm{t}}\right)$ & -0.3177 & -0.2663 & -0.1892 & -0.0771 & -0.3150 & -0.2607 & -0.1126 & -0.1482 \\
& $(-3.35)$ & $(-2.789$ & $(-2.42)$ & $(-0.83)$ & $(-8.19)$ & $(-7.80)$ & $(-2.85)$ & $(-3.48)$ \\
$\Delta \ln \left(\sigma_{\mathrm{i}, \mathrm{t}}\right)$ & 0.8683 & 0.7570 & 0.9533 & -0.1963 & 0.8377 & 0.6519 & 0.7694 & -0.1175 \\
& $(5.02)$ & $(6.02)$ & $(5.83)$ & $(-1.65)$ & $(4.04)$ & $(5.15)$ & $(4.26)$ & $(-0.80)$ \\
$\Delta \ln \left(\mathrm{Notrans}_{\mathrm{i}, \mathrm{t}}\right)$ & -0.1063 & -0.0837 & 0.0089 & -0.0926 & -0.1230 & -0.0820 & 0.0139 & -0.0959 \\
& $(-9.58)$ & $(-7.27)$ & $(0.91)$ & $(-6.54)$ & $(-10.08)$ & $(-6.32)$ & $(1.51)$ & $(-6.15)$ \\
$\Delta \ln \left(\mathrm{Trdsize}_{\mathrm{i}, \mathrm{t}}\right)$ & -0.0460 & -0.0605 & -0.0027 & -0.0578 & -0.0174 & -0.0225 & 0.0316 & -0.0541 \\
& $(-3.94)$ & $(-4.65)$ & $(-0.20)$ & $(-3.26)$ & $(-1.53)$ & $(-1.85)$ & $(3.19)$ & $(-3.50)$ \\
$\mathrm{LP}_{\mathrm{i}, \mathrm{t}}$ & 0.0130 & -0.0013 & 0.0111 & -0.0124 & -0.0202 & -0.0288 & -0.0108 & -0.0180 \\
& $(0.39)$ & $(-0.05)$ & $(0.48)$ & $(-0.36)$ & $(-0.70)$ & $(-1.04)$ & $(-0.58)$ & $(-0.65)$ \\
$100 \Delta \ln \left(\right.$ Reltick $\left._{\mathrm{i}, \mathrm{t}}\right)$ & -0.8281 & -0.6865 & 0.2509 & -0.9374 & -0.4439 & -0.5091 & -0.6028 & 0.0938 \\
& $(-1.96)$ & $(-1.72)$ & $(0.88)$ & $(-1.93)$ & $(-0.87)$ & $(-1.49)$ & $(-1.79)$ & $(0.21)$ \\
$\mathrm{MS}_{\mathrm{i}}^{\mathrm{Xetra}}$ & -0.2864 & -0.1294 & 0.0730 & -0.0564 & -0.1600 & -0.0544 & -0.1406 & 0.0861 \\
$\ln \left(\mathrm{MC}_{\mathrm{i}}\right)$ & $(-1.97)$ & $(-1.00)$ & $(-0.72)$ & $(-0.35)$ & $(-1.36)$ & $(-0.47)$ & $(-1.40)$ & $(0.64)$ \\
$\mathrm{R}^{2}$ & -0.0292 & -0.0303 & 0.0217 & -0.0520 & -0.0525 & -0.0390 & 0.0265 & -0.0655 \\
& $(-2.15)$ & $(-2.56)$ & $(2.16)$ & $(-3.43)$ & $(-4.03)$ & $(-3.00)$ & $(2.57)$ & $(-4.53)$ \\
& 0.4127 & 0.3193 & 0.2469 & 0.1226 & 0.2829 & 0.1994 & 0.1682 & 0.0894 \\
\hline
\end{tabular}




\section{CFS Working Paper Series:}

No.

2007/18

\author{
Günter W. Beck \\ Volker Wieland
}

2007/17 Günter W. Beck

Volker Wieland

2007/16 Silvio Colarossi

Andrea Zaghini

2007/15 Annamaria Lusardi

Olivia S. Mitchell

2007/14 Jean Boivin

Marc P. Giannoni

Ilian Mihov

2007/13 Virgiliu Midrigan

2007/12 Michael Woodford

2007/11 Lars E. O. Svensson Noah Williams

2007/10 Alessandro Calza Tommaso Monacelli Livio Stracca

2007/09 Mark Gertler Antonella Trigari
Title

Money in Monetary Policy Design under

Uncertainty: A Formal Characterization of ECB-

Style Cross-Checking

Money in Monetary Policy Design under

Uncertainty: The Two-Pillar Phillips Curve versus

ECB-Style Cross-Checking

Gradualism, Transparency and Improved

Operational Framework: A Look at the Overnight

Volatility Transmission

Financial Literacy and Retirement Preparedness:

Evidence and Implications for Financial Education Programs

Sticky Prices and Monetary Policy: Evidence from Disaggregated U.S. Data

Menu Costs, Multi-Product Firms, and Aggregate Fluctuations

Robustly Optimal Monetary Policy with NearRational Expectations

Bayesian and Adaptive Optimal Policy under Model Uncertainty

Mortgage Markets, Collateral Constraints, and Monetary Policy: Do Institutional Factors Matter?

Unemployment Fluctuations with Staggered Nash Wage Bargaining

Copies of working papers can be downloaded at http://www.ifk-cfs.de 